\title{
Public Participation in Solid Waste Management Practices within Owerri Urban of Imo State, Nigeria
}

\author{
Nkwoada Amarachi ${ }^{1}$, Alisa Christopher ${ }^{2}$, Duru Ijeoma ${ }^{3}$ \\ Federal University of Technology Owerri, School of Physical Sciences, Department of Chemistry
}

\begin{abstract}
Municipal waste disposal have reached a crucial point in major urban areas in Nigeria especially Owerri urban and householder's readiness to participate in waste management are still declining moreover the problems of indiscriminate dumping of refuse at central places and open dumping and burning at private residents continue to persist. A structured questionnaire was provided to residents of Owerri urban areas addressing lack of knowledge and attitude as a factor in waste recycling, methods of waste disposal, participation and practice using SCHOM analysis that identified 24 active waste dump/disposal sites. ANOVA at 0.95\% value of F calculated was 0.25 and less than the value of $F$ critical at value of 4.25 which shows that the burning and burying of waste was unaffected by usage of bins within any location but rather a habit acquired over the years. Also F calculated in column of ANOVA was less than $F$ critical and showed that different zones exhibit different disposal habits and their levels of participation are affected by levels of quality of surrounding environment, popular trend, sex, age and income. SCHOM participants revealed a trend in volume of waste generated among householders to be Metals $<$ Glasses $<$ Garden waste $<$ Papers $<$ plastics $<$ Kitchen Litter. Analysis showed that Owerri urban residents had high level of awareness in waste sorting and it should be introduced because the public is more likely to participate in recycling programs when they contribute to the designing of such programs.
\end{abstract}

Keywords: Respondents, residents, Owerri, household, practice, waste disposal, participation.

\section{Introduction}

The problems of waste management have continued to beleaguer the entire universe especially Nigeria as presented by ABUJA CITISERVE (2004). According to Adeniran (2005) and Babatunde et al., (2013) with annually generated solid waste in Nigeria been more than 25 million tonnes of $0.66 \mathrm{~kg} / \mathrm{cap} /$ day in urban areas and $0.44 \mathrm{~kg} / \mathrm{cap} /$ day in rural areas, we are certainly heading to a crises stage if unmanaged. Solid waste comes from residential, institutional, commercial, agricultural or even industrial discards while municipal solid waste has emerged as one of greatest generated hazards (Benjamin, Emmanuel \& Gideon, 2014; ABUJA-CITISERVE, 2004). The Management of municipal solid waste consist of practices involving waste generation, collection, sorting, storage, transport, transfer, processing and disposal (Habib, Abdolhossinpari \& Hamed, 2014), which can lead to environmental pollution like land degradation, vector breeding ground, offensive odours, emissions of toxic gases and groundwater contamination if not managed effectively in urban areas as noted by Farasat et al., (2015) and even the formation of leachates which contains heavy metals, microorganisms and radioactive elements (Egharevba, Amengialue, Edobor \& Omoigberale, 2013) especially in dumped open landfills (Olusegun, 2013). Thus municipal waste disposal as reported by Iyanda, Titilope \& Olaniyi (2014) have reached a crucial point in major towns and cities in Nigeria including Owerri urban.

With strategies like public private partnership, Vincent (2000) observed that the private sector participation in waste management is becoming visible as the public sector is enabling the private sector in provision of public services. But willinglines of householders to pay for waste generated is still declining since payment is based on location and type of living area rather than volume of waste generated (Longe, Longe \& Ukpebor, 2009) and as a result private firms restrict their activities to middle and high income neighbourhoods (Yekeen \& Sanusi 2010). But Ohakwe, Nnorom and Iwunze,
(2011) noted that public participation in such waste management programs determine the success of such programs, although studies by Millicent and Ibrahim, (2013) have shown disparity in household satisfaction with waste collection services. However, can public enlightenment on waste disposal improve people's attitude and participation as Afangideh, Joseph and Atu, (2012) noted. There is also the problem of existing dust bins and their serving neighbourhoods and its associated problems (Shubho, Hassan, Hossain \& Neema 2013). Moreover studies have shown that the intimidating and confrontational beaurecratic routine of environmental sanitation exercises in Nigeria causes low participation and no stakeholders' involvement (Achor \& Nwafor, 2014). furthermore household perception that children, women and youths should be disposing the waste generated in the homes could be a challenge (Ramatta, Dennis \& Philip, 2014; Joseph, 2014) since open dumping in open sites remain their familiar method of disposing waste in Owerri Urban (Eze, Orebiyi, Henri \& Onyenwe, 2014). Thus the study will investigate if the "use and dump anywhere" attitude of Owerri urban dwellers as regard waste sorting (Joseph, 2014) is actually do to lack of knowledge as the major limiting factor preventing individuals from waste recycling (Tunmise, 2014) otherwise that the major management method of disposal of waste in Owerri urban are either burning, composting, and burying (Ohaka, Ozor \& Ohaka, 2013), and if educating the citizenry on proper waste disposal practices would influence their practices and perception of waste disposal (Adaogu et al., 2015).

\section{Materials and Method}

\subsection{Study Area}

The study was done in Owerri urban located in the lower part of Imo River basin and situated in the central part of the eastern Nigerian region occupying a land mass of about $11,420 \mathrm{Km}^{2}$ which is relatively small compared to other states but has a high population density of about $230-1400$ 


\section{International Journal of Science and Research (IJSR) \\ ISSN (Online): 2319-7064 \\ Index Copernicus Value (2013): 6.14 | Impact Factor (2014): 5.61}

person $\mathrm{Km}^{2}$, and a home to over 11 million people back in 2005 census. The inhabitants of the basin are mostly Imo and Abia states indigenes while the basin is slightly low-lying pointing towards the south (Niger Delta) but high plain to the north (Nwachukwu, Feng \& Alinnor 2011). The surrounding rivers are mainly the tributaries of the Imo River that discharges into the Niger River and joins the Atlantic Ocean with abundance of clay minerals, gravel, sand, shale and lignite (Nwachukwu, Feng and Alinnor 2010). The geology of the study area is made up of plain soil of about 0.05-2.0 $\mathrm{mm}$ in size which has good drainage capacity (Okoro, Chukwuma, Chukwuma \& Ugwu 2015) and has arable land. Geographically, the basin is a $140 \mathrm{Km}$ north-south sedimentary syncline. Climatic condition is characterised by two seasons: the rainy from April to October with temperature varies between $25^{\circ} \mathrm{C}$ to $29^{\circ} \mathrm{C}$, the dry season starts in November with very low humidity and clouds are absent. The Harmattan caused by harsh north easterly wind is felt within the season when the eastern wind blowing from the Mediterranean Sea crosses the Sahara desert to the southern part of Nigeria (Amadi et al., 2015).

It is mainly occupied by students, civil servants, farmers, artisans and traders (Adogu et al., 2015). According to Ohaka, Ozor and Ohaka (2013) they generate large volumes of waste which is disposed indiscriminately and unsystematically as shown in figure 1 below. Hence the problems of indiscriminate dumping of refuse at central places and open burning at private residents continue to persist.

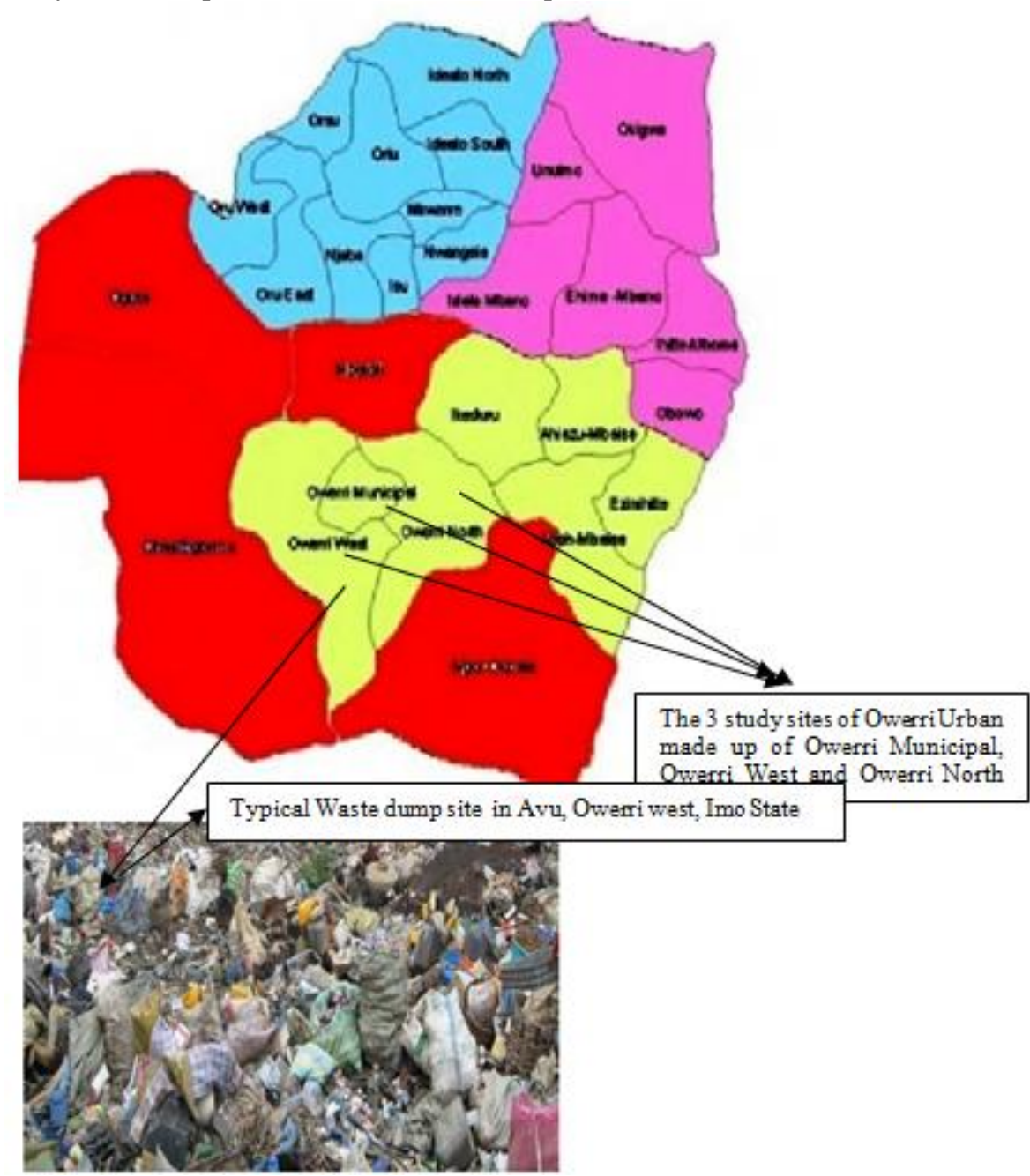

Figure 1: Map of Imo State of Nigeria, showing the study sites of the three Local governments that make up Owerri Urban (IMO STATE BLOG, 2015; Amadi et al., 2012).

\subsection{Instrument of Study}

The research was based on survey of questionnaires distributed to residents of Owerri Urban. A total of 300 questionnaires were given out at 100 each to residents of Owerri Municipal, Owerri West and Owerri North Local Government Areas (LGA) as shown in the map in figure 1 above. The Choice of the respondents were based on the assumption that residents in schools, churches, homes, offices and markets (SCHOM) with stable addresses would not only return the questionnaire but would produce responses that are fit for purpose.
Using modified Ulaeto, Nnorom, Alisa and Ewuzie, (2015) approach, the research was developed into simple and short sentences by team of experts. Each questionnaire had section a on bio-data comprising of 10 questions, section B of 38 questions on waste disposal knowledge and section $\mathrm{C}$ comprising of 12 questions on practices and perception. Some of the questions were open ended enabling individual opinions and some close ended to prevent deviation while some had multiple options to broaden choices. The study was carried out between June to November spanning an entire six months which allowed the respondents enough time for measured distribution of questionnaire and for respondents to

\section{Volume 5 Issue 3, March 2016}




\section{International Journal of Science and Research (IJSR) \\ ISSN (Online): 2319-7064}

Index Copernicus Value (2013): 6.14 | Impact Factor (2014): 5.61

reflect over their responses before submission. The data obtained were analysed using simple Microsoft excel and ANOVA

\section{Results and Discussions}

The questionnaires were collected and analysed. A total of 122 questionnaires were returned from SCHOM respondents of evaluation of Owerri municipal, Owerri west and Owerri North Local governments respectively. The figure 2 below shows that $37.70 \%$ of respondents were resident in Owerri Municipal, 31.96\% were in Owerri west and 30.34\% lives in Owerri North. Findings further revealed that the highest male and female respondents were living in Owerri Municipal while the percentage of female respondents in Owerri North and Owerri west area were the same. This may be a reflection of numerous civil servants and traders who come into the municipal during working hours than the surrounding urban areas (Adaogu et al., 2015).

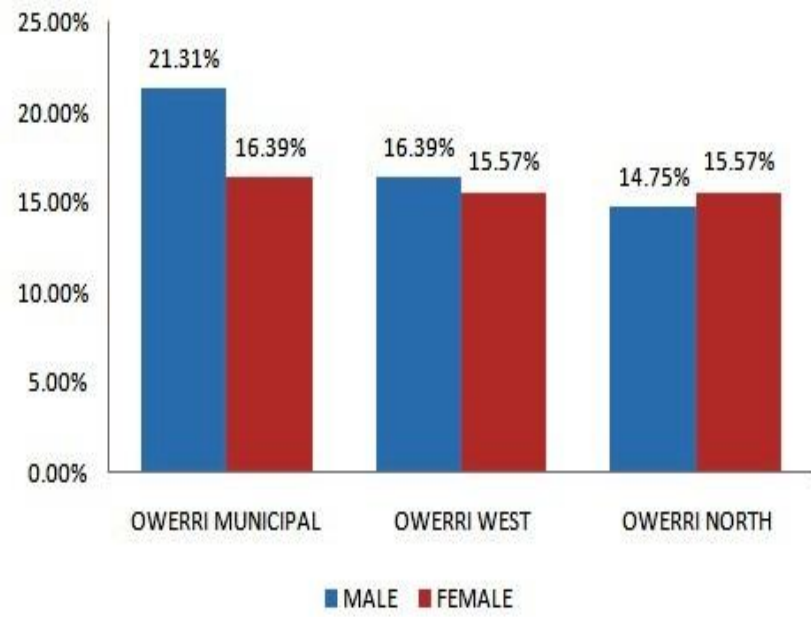

Figure 2: Bar chart of respondents in the 3 zones of Owerri Urban showing the ratio of male and female participants.

\subsection{Biodata Analysis}

The bio-data profile in figure 3 below shows that majority of the respondents were below 36 years old which may be an indication of younger population existing in Owerri urban who actively according to Ramatta, Dennis \& Philip (2014), Joseph (2014) are responsible for disposal of waste generated in their homes. Similarly the same younger populace may be having late marriages as majority of the respondents were single or unmarried. The number of male respondents were higher than the female respondents while the working respondents surpasses the student respondents which may be due to traders who flood the city main markets during working hours than in the surrounding urban areas (Adaogu et al., 2015)

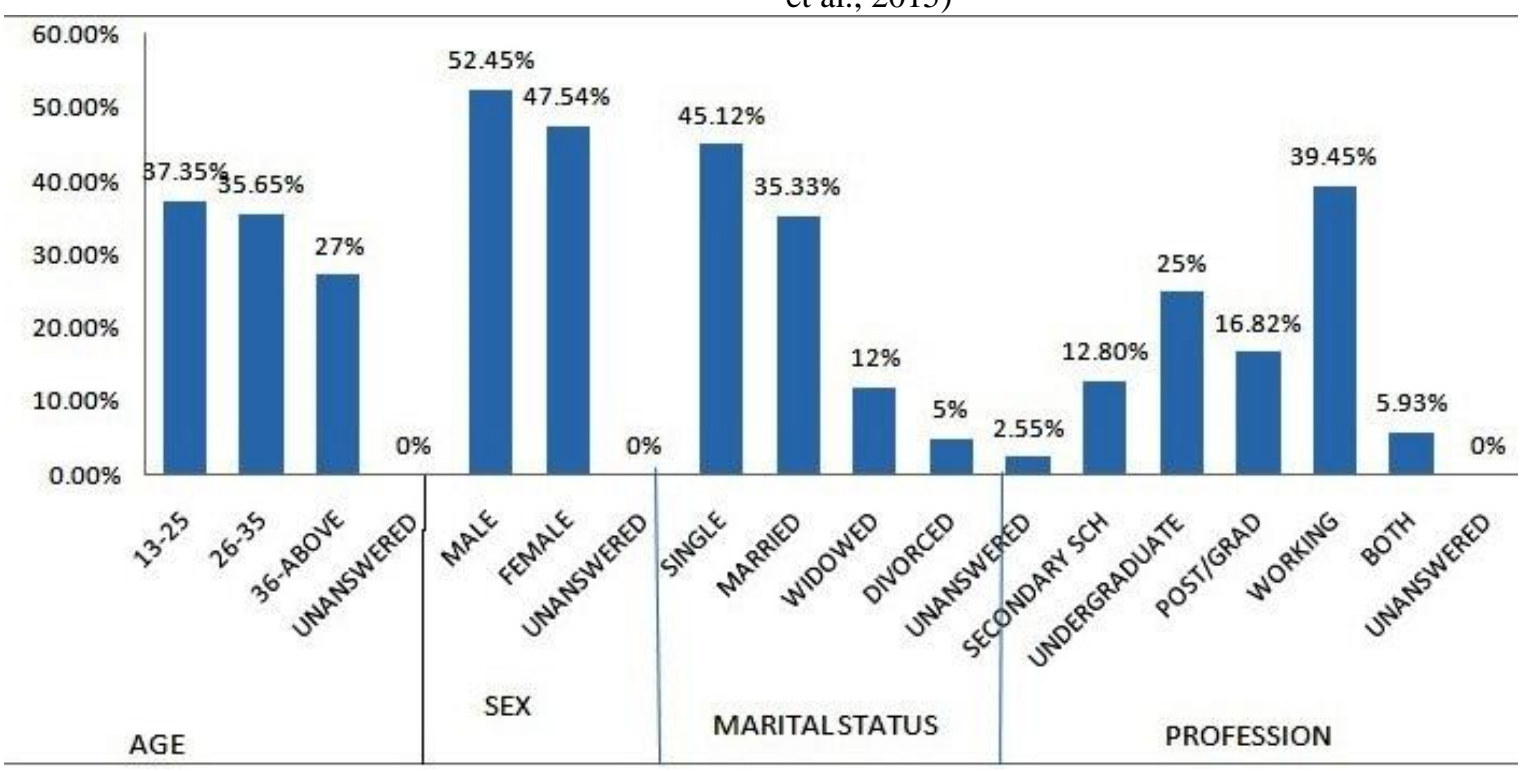

Figure 3: Bio-data profile of respondents in Owerri Urban

\subsection{Waste Disposal Knowledge Analysis}

Majority of the respondents believed they are familiar with the term waste and waste disposal. Over $80 \%$ of municipal and Owerri North respondents believed that waste was unwanted substances while responses in Owerri west varied from unwanted to unused and condemned substances this perception according to Adogu et al., (2015) is because of the prevalent knowledge and recycling activities in the area. There was no trend in the volume of waste generated from SCHOM analyses, however majority of the respondents in the three Owerri urban zone agreed they would rather mix up the whole waste together as evident in figure 1 above which according to Joseph (2014) is as a result of already established habit of mix and dump waste attitude and will eventually end up in street corners, gutters, open spaces and 


\section{International Journal of Science and Research (IJSR) \\ ISSN (Online): 2319-7064 \\ Index Copernicus Value (2013): 6.14 | Impact Factor (2014): 5.61}

waste land as noted by Vincent (2000). The Owerri municipal respondents were keen to baggage their waste and dispose it at designated sites while respondents in Owerri west would baggage and dump at abandoned sites or overflowing bins while majority in Owerri North agreed that they would baggage and bury or get it burnt, a practice of which Adeolu, Enesi, and Adeolu (2014) remarked was prevalent among secondary school students. Studies shows that majority of women, children and youths are responsible for waste disposal also reflected by just $27 \%$ of respondents been above 35 years when compared to over $70 \%$ that were below 35 years who regularly visit dump sites for disposal as shown by their indication of how often the waste bins are carted away by designated agencies (Ramatta, Dennis and Philip 2014; Joseph 2014).

A two way ANOVA with replication at 0.05 significant level was used to analyse the data and test the significance of the response of respondents that burning and burying of waste which Eze, Orebiyi, Henri and Onyenwe, (2014) noted was the commonest method of waste disposal in Imo State is as a result of insufficient collection bins or inadequate disposal points.

Table 1: ANOVA test of significance of respondents ANOVA

\begin{tabular}{|c|c|c|c|c|c|c|}
\hline Source of Variation & SS & $d f$ & MS & $F$ & $P$-value & F crit \\
\hline Sample & 67 & 2 & 33.5 & 0.25146 & 0.78295112 & 4.256494729 \\
\hline Columns & $4.55 E-13$ & 2 & $2.2737 E-13$ & $1.71 E-15$ & 1 & 4.256494729 \\
\hline Interaction & $-4.5 E-13$ & 4 & $-1.137 E-13$ & $-8.5 E-16$ & \#NUM! & 3.633088512 \\
\hline Within & 1199 & 9 & 133.222222 & & & \\
\hline Total & 1266 & 17 & & & & \\
\hline
\end{tabular}

The value of $\mathrm{F}$ calculated was 0.25 and less than the value of F critical at value of 4.25 which shows that the burning and burying was unaffected by presence or absence of bins within any location but rather a habit formed over the years as remarked by Vincent (2000). Also the value of $\mathrm{F}$ calculated in column was less than $\mathrm{F}$ critical confirming further that different zones exhibit different disposal habits because their level of participation is affected by level of quality of surrounding environment, popular trends, sex, age and income (Ohakwe, Nnorom \& Iwunze 2011)

Thus according to Longe, Longe and Ukpebo (2009), Milicent and Ibrahim (2013) mentioned that progress would be achieved by creating awareness on domestic education, prompt responses and effective monitoring and penalty for offenders because unsubsidized disposal would lead to open dumping or burning of waste. Most of the respondents described the general problem of overflowing bins at disposal sites, waste bins located along major roads, non punishment of offenders who drop their waste along the roads and general transport of waste with open van or open waste loaders as a common observable general trend. Likewise studies have shown that is as a result of irregular funding of waste management corporations that leads to improper infrastructure, poor maintenance and low grade of existing facilities which maybe overstretched by continuous urban growth. (Habib, Abdolhossinpari, Hamed \& Hossein 2014). The SCHOM evaluation in table 2 below identified about 24 dumpsites to be the active and regular dumpsites in the three zones that were studied.

Table 2: location of some major waste bin sites in Owerri urban

\begin{tabular}{l|l|l}
\hline OWERRI MUNICIPAL & OWERRI WEST & OWERRI NORTH \\
\hline AKACHI ROAD & EZIOBODO & AKWAKUMA \\
\hline AKANCHAWA & IHIAGWA & AMAKOHIA \\
\hline ALADINMA & NEKEDE MECHANIC VILLAGE & EGBU ROAD \\
\hline DOUGLAS ROAD & NELEDE & ORII MECHANIC VILLAGE \\
\hline EMMANUEL COLLEE & OLD NEKEDE ROAD & ORII \\
\hline IKENEGBU & UMUGUMA & URATTA \\
\hline NEW MARKET OWERRI & & \\
\hline TRANS-EGBU & & \\
\hline ONITSHA ROAD & & \\
\hline ROYCE ROAD & & \\
\hline WAREHOUSE OWERRI & & \\
\hline WORLD BANK & & \\
\hline
\end{tabular}

It would be observed that Owerri municipal had 12 major location dumpsites while each of Owerri west and Owerri north had 6. Most of the sites mentioned were either along major roads or roads along residential buildings. The effect of this would be to examine the spatial distribution and number of these dustbins in Owerri urban to elucidate as noted by Shubho, Hassan, Hossain and Neema, (2013) if they are in clustered pattern or regular pattern. In addition the issue of ineffective communication and poor participation during monthly sanitation exercises done in Owerri Urban could be improved with sufficient dust bins and good road network for carriage vans using spatial distributions in Owerri urban (Achor and Nwafor, 2014).

\subsection{Practices and Perceptions.}

The dumpsites located around the three zones of study were described by over $80 \%$ of respondents as unsafe, contaminated and toxic. These Adaogu et al., (2015) suggested that Owerri urban residents therefore require adequate provision of refuse collection services at specific dump sites and proper waste awareness sensitization education. Moreover many of the respondents described that house to house waste collection during early mornings was appropriate for their residents stating that the initial problems of dump and abandon was because of zone or central collection points created over the years which was no longer sufficient. Similarly respondents generally agreed that recycling is the ultimate solution to voluminous waste generated annually in the 3 zones which Tunmise (2014) noted that when citizens are more likely to participate in waste recycling when they are exposed to recycling programs. In addition, they likelihood increases when they contribute to the designing of the program about the gains of recycling and how to sort out the waste because awareness and participation makes the difference between waste recyclers and non recyclers.

In order to evaluate individual disposal practices and waste sorting attitudes, respondents were given a table with different types of waste colour codes to indicate how and where they would sort out their different waste using colour 


\section{International Journal of Science and Research (IJSR) \\ ISSN (Online): 2319-7064 \\ Index Copernicus Value (2013): 6.14 | Impact Factor (2014): 5.61}

coded boxes. The figure 4 below shows that greater number of participants would bin metals in red bin boxes, glasses in blue bin boxes, papers and garden waste in brown bin boxes, plastics in yellow bin boxes and garden waste in green bin boxes. The bar chart also identified that the most common household waste generated are metals, papers, plastic, glasses, kitchen litters and garden waste.

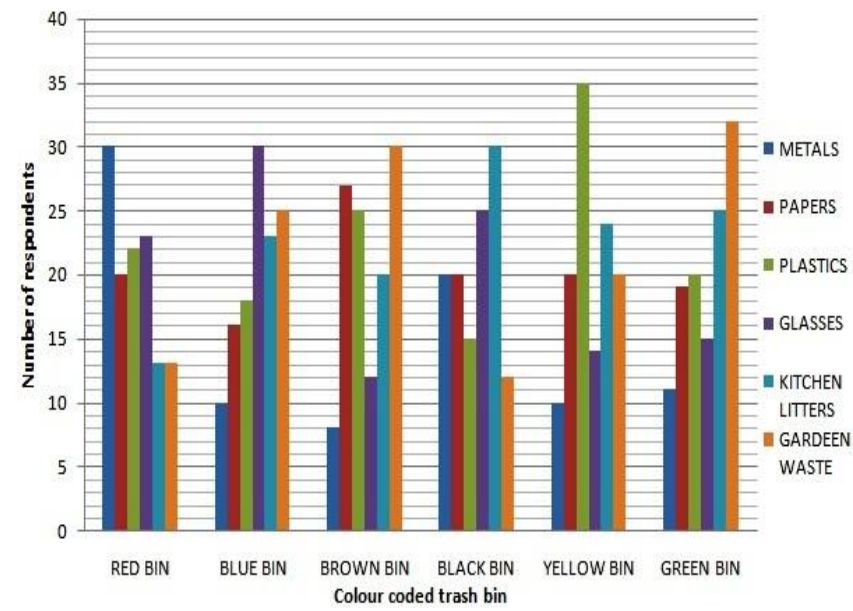

Figure 4: Types of household wastes disposed in Owerri urban using colour coded boxes

The addition of the total number of each type of waste in each of the colour coded trash bins establishes the following order of household waste: Metals $<$ Glasses $<$ Garden waste $<$ Papers $<$ plastics $<$ Kitchen Litter relative to volume generated and consumed. This also corresponds to earlier findings that: organic waste, paper, nylon, glass, metals, plastics and rubber are most common household waste disposed in Nigeria (Benjamin, Emmanuel and Gideon, 2014; Babatunde et al., 2013; Bichi \& Amatobi 2013).

\section{Conclusion and Recommendation}

The volume of six common types of waste generated are in these order: Metals $<$ Glasses $<$ Garden waste $<$ Papers $<$ plastics $<$ Kitchen Litter showing a high level of awareness in waste sorting and separation, it would be significant for state government of the Owerri urban to introduce waste sorting and collection on different dates suitable to each zone (Ohaka, Ozor \& Ohaka, 2013). The 24 major waste dump sites identified were street major street roads or residential streets identified, it would be important for government to relocate some dump sites, remove old bin collectors, replace small bin collectors with larger ones, strengthen waste company facilities and personnel and introduce regular dump site supervision and bi-annual review of spatial distribution of waste sites (Shubho, Hassan, Hossain and Neema 2013). Also capacity building in the area of public private partnership should be established for Owerri urban dwellers to strengthen partnership. (Yekeen, 2010).

\section{References}

[1] ABUJA CITISERVE, Estimates of Waste Generation Volumes and Income Potential in Abuja, SLGP Consultants' Report Number (2004) 805 (Original Number 174) DFID CNTR: 000512A, Department for International development.
[2] Achor .P.N, Nwafor .A.U, Participatory decision making: a model for the effective involvement of stakeholders in waste management projects in Nigeria, African Journal of Social Sciences (2014) 146-162 Volume 4 Number 1.

[3] Adeniran .K.A, Assessment of solid waste management in Ilorin metropolis, Kara state, Nigeria USEP, Journal of research information in civil Engineering, (2005) Vol 2. No 1.

[4] Adeolu .A.T, Enesi .D.O, Adeolu .M.O, Assessment of Secondary School Students' Knowledge Attitude and Practice towards Waste Management in Ibadan, Oyo State, Nigeria, Journal of Research in Environmental Science and Toxicology (2014) 66-73 Vol. 3(5).

[5] Adogu, .P.O.U, Uwakwe .K. A, Egenti .N. B, Okwuoha .A. P, Nkwocha I.B, Assessment of Waste Management Practices among Residents of Owerri Municipal Imo State Nigeria, Journal of Environmental Protection 6 (2015) 446-456.

[6] Afangideh .A, Joseph .K, Atu .J.E, Attitude of urban dwellers to waste disposal and management in Calabar, Nigeria, European journal of sustainable development (2012) Vol 1 No 1.

[7] Amadi .A.N, Olasehinde .P.I, Okosun .E.A, Okoye .N.O, Okunlola .I.A, Alkali .Y.B, Dan-Hassan .M.A, A Comparative Study on the Impact of Avu and Ihie Dumpsites on Soil Quality in Southeastern Nigeria, American Journal of Chemistry (2012) 2(1): 17-23.

[8] Babatunde .B.B, Vincent .A.I.F, Woke G.N, Atarhinyo .E, Aharanwa .U.C, Green .A.F, Isaac J.O, Comparative analysis of municipal solid waste (MSW) composition in three local government areas in Rivers State, Nigeria, African Journal of Environmental Science and Technology (2013) 874-881 Vol 7(9).

[9] Benjamin .T.A, Emmanuel .E.O, Gideon .A.D, Characterization of Municipal Solid Waste in the Federal Capital Abuja, Nigeria, Global Journal of Science Frontier Research: Environment \& Earth Science (2014) Vol 14 Issue 2 Version 1.0

[10]Bichi .M.H, Amatobi .D.A, Characterization of household solid wastes generated in Sabon-gari area of Kano in Northern Nigeria, American Journal of Research Communication (2013) Vol 1 (4).

[11]Egharevba .AP, Amengialue O.O, Edobor .O, Omoigberale .M.N.O, Microbiological and PhysicoChemical Quality Assessment of Solid Waste Dumpsites in Benin City, Nigeria, International Journal of Agriculture and Biosciences, (2013) 2(6): 344-348.

[12]Eze .C.C, Orebiyi .J.S, Henri .U.A, Onyenwe .T.E, Multivariate Analysis of Non-Biodegradable Waste Disposal in Imo State Southeast Nigeria, Journal of Environment and Earth Science (2014) Vol.4, No.4.

[13] Farasat .A, Yawar .A, Attarad .A, Qasim .K, Nawazish .A, Rizwan .K, Jarrar .H.I, Municipal Solid Waste Quantity Composition and Current Management Practices in Gilgit City, Gilgit-Baltistan Pakistan, International Journal of Environmental Monitoring and Analysis (2015) 3(5): 282-287.

[14] Habib .F, Abdolhossinpari .Z, Hamed .F, Hossein .M, Municipal solid waste characterization and it is assessment for potential compost production: A case study in Zanjan city Iran, American Journal of Agriculture and Forestry (2014) 2(2): 39-44. 


\section{International Journal of Science and Research (IJSR) \\ ISSN (Online): 2319-7064 \\ Index Copernicus Value (2013): 6.14 | Impact Factor (2014): 5.61}

[15] Iyanda .T.A, \& Olaniyi .O.A, Assessment of Municipal Waste Disposal Methods: A Case Study of Ibadan Nigeria, Chemistry and Materials Research (2014) Vol 6 No12.

[16] Joseph .O.O, Analysis of public and private agents in refuse disposal services in urban towns in Delta state, Nigeria, European Journal of Business and Social Sciences (2014)1-10 Vol. 2, No.11

[17]Longe .E.O, Longe .O.O, Ukpebor E.F, People's perception on household solid waste management in Ojo local government area in Nigeria, Iran. J. Environ. Health. Sci. Eng (2009) 201-208 Vol 6 No. 3.

[18] Millicent .A.A, Ibrahim .Y, Householders' satisfaction towards solid waste collection services of zoomlion Ghana ltd in WA, Ghana, European Scientific Journal November (2013) Vol 9 No.32

[19] Nwachukwu .M.A, Feng H, Alinnor .J, Assessment of heavy metal pollution in soil and their implications within and around mechanic villages, Int. J. Environ Sci Tech (2010) 347-358 7(2).

[20] Nwachukwu .M.A., Feng .H, Alinnor .J, Trace Metal Dispersion in Soil from Auto-Mechanic Village to Urban Residential Areas in Owerri, Nigeria,Urban, Environmental Pollution 2010, Procedia Environmental Sciences 4 (2011) 310-322

[21] Ohaka .A.R, Ozor .P.E, Ohaka .C.C, Household waste disposal practices in Owerri municipal council of Imo state, Nigerian Journal of Agriculture, Food and Environment (2013) 9(2):32-36.

[22] Ohakwe .J, Nnorom .I.C, Iwunze .I.S, Survey of attitude of residents towards environmental deterioration in Nigeria and factors influencing their willinglines to participate in reducing the trend: A case study of waste management, Trends in Applied Sciences Research (2011) 6 (2): 154-164.

[23] Okoro .A.C, Chukwuma .G.O, Chukwuma .E.C, Ugwu .I.E, Distribution Of Heavy Metals And Other Physicochemical Properties Of Soil At Automobile, International Journal of Scientific \& Engineering Research (2015) Vol 6 Issue 2.

[24] Olusegun .O.I, Geologic And Geotechnical Evaluation Of An Open Landfill For Sanitary Landfill Construction In Ilorin Southwestern Nigeria, Journal of Environment and Earth Science (2013) Vol. 3 No.3.

[25] Ramatta .M.Y, Dennis .C, Philip .B.A, Domestic waste disposal practice and perceptions of private sector waste management in urban Accra, BMC Public Health (2014), 14:697 http://www.biomedcentral.com/14712458/14/697.

[26] Shubho .M.T.H, Hassan M.T, Hossain M.R, Neema M.N, Quantitative Analysis of Spatial Pattern of Dustbins and its Pollution in Dhaka City--A GIS Based Approach, Asian Transactions on Engineering (2013) Vol 03 Issue 04.

[27] Tunmise .A.O, Individual Attitude toward Recycling of Municipal Solid Waste in Lagos Nigeria, American Journal of Engineering Research (2014) 78-88 Vol 3, Issue-07.

[28] Ulaeto .S.B, Nnorom .I.C, Alisa .C.O, Ewuzie .U, Survey of waste disposal methods in Awka Metropolis, Journal of applied science \& environmental management (2015) 311-316 Vol 19 (2).
[29] Vincent .I.O, Private sector participation and municipal waste management in Benin City Nigeria, Environment and Urbanization (2000) Vol 12 No 2.

[30] Yekeen. A.S, Capacity issues of private sector participation in Urban Solid Waste management in Nigeria, Human and Social sciences Journal (2010) 5 (1): 07-18.

\section{Author Profile}

Nkwoada Amarachi is a lecturer at the Federal University of Technology Owerri, Nigeria (FUTO). He is now pursuing Ph.D in Environmental chemistry.

Alisa Christopher (Ph.D) is a research fellow whose interest lies on the use of flavonoids to better mans health challenges

Duru Ijeoma (Ph.D) is a research fellow in department of chemistry, FUTO, Nigeria. Interest lies in synthesis, modification and characterization of organic molecules as well as extraction and isolation of bioactive compounds from natural products. 